\title{
Recent Development Trend of Electronic Commerce Research: 2000 to 2016
}

\author{
Yann-Jy Yang \\ Chihlee University of Technology \\ E-Mail: yjyang@mail.chihlee.edu.tw \\ Chih-Chien Wang \\ National Taipei University \\ E-Mail: wangson@mail.ntpu.edu.tw \\ Chien-Chang Chen \\ Tamkang University \\ E-Mail: ccchen34@mail.tku.edu.tw
}

\begin{abstract}
The current study aims to identify the recent research trend of electronic commerce research and report theoretical background used in the electronic commerce research articles. By searching the five electronic commerce research journals, including Electronic Commerce Research, Electronic Commerce Research and Applications, International Journal of Electronic Commerce, Journal of Electronic Commerce Research, and Journal of Theoretical and Applied Electronic Commerce Research listed in the Social Sciences Citation Index (SSCI) database in a seventeen years period between January 2000 and December 2016, we found 1,205 electronic commerce research articles. By analyzing these articles, the current study maps the trend and reveals the highly influence research article. The current study also reveals theories that used in the electronic commerce research articles. The results provide fundamental insights on the recent research of electronic commerce.
\end{abstract}

Keywords: Bibliometric, Literature Review, Electronic Commerce, Social Science Citation Index, SSCI 


\section{INTRODUCTION}

Electronic commerce is currently becoming a blooming research field. Thanks to the advances of information communication technology infrastructure, as well as the high penetration of internet and mobile communication connection, people now can do a variety of commerce activities online. Enormous online application and activities are available worldwide without time and geographic scope limitation. Electronic commerce is not just a fashion term, it is now a part of our daily life.

Electronic commerce are being adopted by nearly all industry. Electronic commerce enrich the means that managers do business transaction as well as manage their organizations. The electronic commerce research is also blooming for the past few decades and attracts the focus from both academics and industry of various fields.

This study aims to provide a comprehensive understanding of recent trends of electronic commerce research. Electronic Commerce can refer to the online transactions of buying or selling merchandises and service. Nevertheless, some business activities are also regarded as electronic commerce although these activities are not directly linked to buying or selling some things. There is no consensus on the scopes of electronic commerce. There is also no consensus on the definition of electronic commerce (Ngai \& Wat, 2002). In the current study, we aim to explore the research topics and scopes of electronic commerce. To accomplish this aim, we used bibliometric and text mining techniques to analyze the articles published in electronic commerce relative journals. The electronic commerce journals in the current study are defined by the journals with the term of "electronic commerce" in their journal titles. To limit our research scope, only electronic commerce relative journals listed in Science Citation Index (SCI) and Social Science Citation Index (SSCI) are included in the current study. The current study makes use of bibliometric approach and text mining to reveal research trend of electronic commerce research, and to serve as a roadmap for both academics and practitioners.

The purposes of this study are twofold: (1) Analyze distribution of electronic commerce articles, such as publication years and countries of authors, published journals, and citation times. (2) Analyze the theoretical background of electronic commerce research by analyze the abstracts of the electronic commerce articles. This paper is structured in four sections. The current section provides a brief introduction for this study. Then, the second section introduces bibliometric that used in the current study. Next, this study explains the analysis results. Finally, we conclude the article with a discussion of limitations and implications for future research. 


\section{METHODS}

The study searched titles and abstracts of electronic commerce research articles to identify research topics electronic commerce. The sources of databases were Social Science Citation Index (SSCI) and Sciences Citation Index (SCI). The study chose $\mathrm{SSCI} / \mathrm{SCI}$ database since it earned a good reputation as the leader among electronic database of academic literature. This study restricted articles published in the following five journals with the terms of "electronic commerce" in their journal names: Electronic Commerce Research, Electronic Commerce Research and Applications, International Journal of Electronic Commerce, Journal of Electronic Commerce Research, and Journal of Theoretical and Applied Electronic Commerce Research. The current study did not include the Journal of Organizational Computing and Electronic Commerce since it contains two sub fields: Organizational Computing and Electronic Commerce. It is not easy to discriminate papers of organizational computing from electronic commerce that are published in the Journal of Organizational Computing and Electronic Commerce. Only papers published in the period between 2000 and 2016 are included in the current study.

The current study collected 1,419 articles. Among them, 214 articles were not included in the current study since they were editorial materials (170 articles), review (40 articles), correction ( 3 articles), and biographical item ( 1 article). The remained 1,205 articles are regular research papers. To confine the range of the articles to research articles, the study selected only the 1,205 regular articles for bibliometric and text mining analysis. Figure 1 revealed the number of electronic commerce articles by years. Based on figure 1, we can find that the number of published electronic commerce articles excess one hundred per year since 2010. The peak year was 2015, in that year the electronic commerce journals published totally 128 articles.

The current study only includes articles collected in the SSCI database. Papers were not included in the current study if they were not collected in the SSCI database, even these papers were published in the selected journals during the selected period. For examples, the journal "Electronic Commerce Research" was included in SSCI database since 2008, which means that papers published in "Electronic Commerce Research" in and before 2007 were not included in the current study. Another example is the "Journal of Theoretical and Applied Electronic Commerce Research" that was include in SSCI database since 2014, which means that papers published in "Journal of Theoretical and Applied Electronic Commerce Research" in and before 2013 were not included in the current study.

This study aims to explore the recent development of electronic commerce research by the identified 1,205 research articles published in electronic commerce 
relative journals. Although the articles included in the current study were not exhaustive, the current study hopes to serve as a comprehensive base for an understanding of recent trend of electronic commerce research. This study collected the bibliographic data of all the 1,205 electronic commerce research articles to observe distribution of publication years, countries of authors, published journals, and cited times.

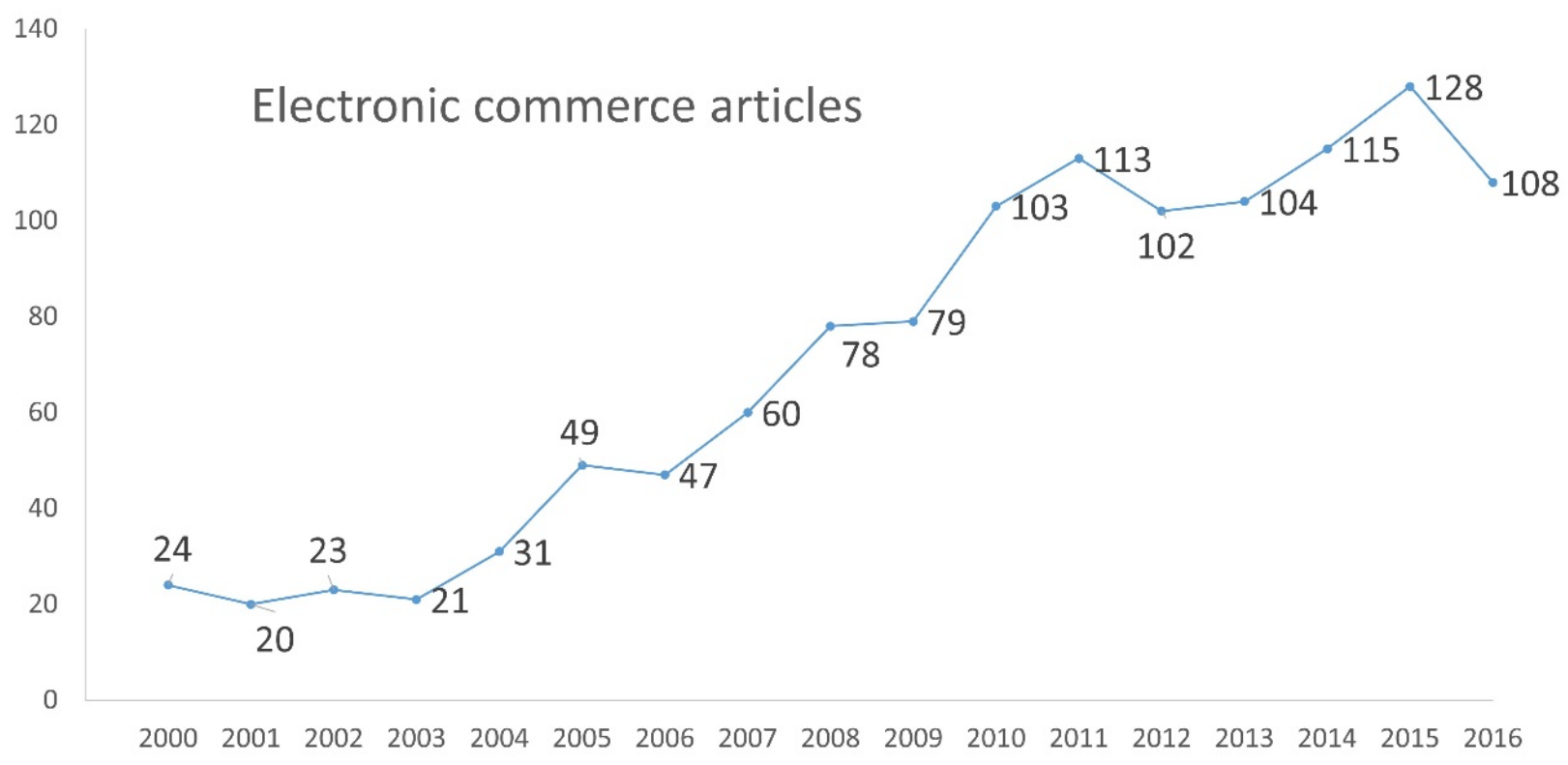

Figure 1 Electronic Commerce Publications from 2000 to 2016

\section{RESULTS}

\section{Distribution of the Year of Publication}

Figure 1 and Table 1 illustrate the annual number of published electronic commerce research articles from 2000 to October 2016. The blossoming of computer and information technology enhance the development of electronic commerce activities. As revealed in Fig. 1, only 20s to 31 electronic commerce research articles were published per year before 2004. Nevertheless, the amount of published articles dramatically increased from 49 in 2005 to 103 articles in 2010 and to 128 in 2015. The increase in the number of electronic commerce research articles reflected the popular of electronic commerce activities, which demonstrates that academics and researchers gradually pay attention to electronic commerce research. 
Table 1 Electronic Commerce Publications by Journals from 2000 to 2016

\begin{tabular}{|c|c|c|c|c|c|c|}
\hline & $\begin{array}{c}\text { Electronic } \\
\text { Commerce } \\
\text { Research }\end{array}$ & $\begin{array}{l}\text { Electronic } \\
\text { Commerce } \\
\text { Research and } \\
\text { Applications }\end{array}$ & $\begin{array}{l}\text { International } \\
\text { Journal of } \\
\text { Electronic } \\
\text { Commerce }\end{array}$ & $\begin{array}{l}\text { Journal of } \\
\text { Electronic } \\
\text { Commerce } \\
\text { Research } \\
\end{array}$ & $\begin{array}{c}\text { Journal of } \\
\text { Theoretical and } \\
\text { Applied Electronic } \\
\text { Commerce Research }\end{array}$ & $\begin{array}{l}\text { Sub } \\
\text { Total }\end{array}$ \\
\hline 2000 & & & 24 & & & 24 \\
\hline 2001 & & & 20 & & & 20 \\
\hline 2002 & & & 23 & & & 23 \\
\hline 2003 & & & 21 & & & 21 \\
\hline 2004 & & & 26 & 5 & & 31 \\
\hline 2005 & & 29 & 20 & & & 49 \\
\hline 2006 & & 26 & 21 & & & 47 \\
\hline 2007 & & 43 & 17 & & & 60 \\
\hline 2008 & 13 & 26 & 18 & 21 & & 78 \\
\hline 2009 & 16 & 27 & 19 & 17 & & 79 \\
\hline 2010 & 18 & 44 & 20 & 21 & & 103 \\
\hline 2011 & 18 & 55 & 20 & 20 & & 113 \\
\hline 2012 & 18 & 43 & 16 & 25 & & 102 \\
\hline 2013 & 25 & 37 & 19 & 23 & & 104 \\
\hline 2014 & 25 & 34 & 15 & 23 & 18 & 115 \\
\hline 2015 & 24 & 53 & 15 & 20 & 16 & 128 \\
\hline 2016 & 21 & 41 & 21 & 15 & 10 & 108 \\
\hline Sub Total & 178 & 458 & 335 & 190 & 44 & 1205 \\
\hline
\end{tabular}

\section{Distribution of Electronic Commerce Research Articles by Journals}

Table 1 also reveals distribution of research articles by journals. The "International Journal of Electronic Commerce" was the first journal included in the SSCI database, following by the "Electronic Commerce Research and Applications" (since 2005), "Journal of Electronic Commerce Research" (since 2008), "Electronic Commerce Research" (since 2008), and "Journal of Theoretical and Applied Electronic Commerce Research" (since 2014). In 2004, there were five articles of the "Journal of Electronic Commerce Research" in the SSCI database. Nevertheless, there was no articles of the "Journal of Electronic Commerce Research" between 2005 and 2007 in the SSCI database. Most of the electronic commerce research articles were published in the "Electronic Commerce Research and Applications" (458 articles), following by "International Journal of Electronic Commerce" (335 articles), "Journal 
of Electronic Commerce Research" (190 articles), "Electronic Commerce Research" (178 articles), and "Journal of Theoretical and Applied Electronic Commerce Research" (44 articles).

\section{Distribution by Authors' Countries}

Table I reveals distribution of authors' countries of the 1,205 electronic commerce studies. Based on author affiliations, the study identified countries producing the most electronic commerce publications among the period between 2000 and 2016. The five most prolific countries in electronic commerce research were USA (37.26\%), Taiwan (14.69\%), China (14.44\%), South Korea (8.63\%), and Germany (5.15\%). Scholars of USA, Taiwan, China, South Korea, and Germany played important roles and were interested in electronic commerce research.

\section{Highly Influence Electronic Commerce Research Articles}

Table 3 reveals the highly influence electronic commerce research articles. As Table 3 revealed, there were 21 electronic commerce research articles that received more than 100 citations. The article published by Pavlou (Pavlou, 2003) in 2003 receive 634 citations. Articles published by Lee and Turban (M. K. Lee \& Turban, 2001) in 2001 received 339 citations. Park, Lee, and Han (Park, Lee, \& Han, 2007) in 2007 received 274 citations. McKnight and Chervany (D Harrison McKnight, 2001) in 2001 received 266 citations. These 21 highly influence articles were published in International Journal of Electronic Commerce (17 articles) and Electronic Commerce Research and Application (4 articles), since these two journals were the first two journals which were included in SSCI database.

\section{Theoretical Background of Electronic Commerce Research}

Keywords of academic articles can help others find the articles quickly and accurately. Most, if not all, journals request authors to provide some keywords for their journal articles. These keywords are usually highly relevant to the focus of research articles. Thus, some articles include the used theories in the keyword list. The current study check all the keywords of the 1,205 electronic commerce research articles to find out the theoretical background of these electronic commerce research. Based on the review of keywords, we obtained the theories use in the electronic commerce research articles, as Table 4 indicates. Some theories used the term of "model" or "law" instead of "theory". The theories without the term of "theory" in their theory names are still included in the list. However, no all keywords which contain the term "theory", "model" or "law" are included in the theory list. For 
examples, the keywords of "theory development", "business model", "copyright law" are not name of theory. In addition, the list in the Table 4 does not include the theories/model relative to algorithm and theories used for data analysis. We check the terms one by one to make sure the list in the Table 4 are theories.

Not all authors would include the used theories in the keywords since most journals only allow authors to provide no more than five or ten keywords for their articles. Thus, the Table 4 does not include all theories included in the electronic commerce research. Nevertheless, the Table 4 is still useful since that it can serve as a reading list for novices in electronic commerce research.

Table 2 Electronic Commerce Publications by Countries

\begin{tabular}{|c|c|c|}
\hline Countries & Articles & Percentage $(\%$ of 1,205$)$ \\
\hline USA & 449 & $37.26 \%$ \\
\hline Taiwan & 177 & $14.69 \%$ \\
\hline China & 174 & $14.44 \%$ \\
\hline South Korea & 104 & $8.63 \%$ \\
\hline Germany & 62 & $5.15 \%$ \\
\hline Canada & 56 & $4.65 \%$ \\
\hline Australia & 54 & $4.48 \%$ \\
\hline England & 50 & $4.15 \%$ \\
\hline Spain & 49 & $4.07 \%$ \\
\hline Netherlands & 41 & $3.40 \%$ \\
\hline Singapore & 34 & $2.82 \%$ \\
\hline Greece & 28 & $2.32 \%$ \\
\hline Italy & 24 & $1.99 \%$ \\
\hline Finland & 19 & $1.58 \%$ \\
\hline Belgium & 17 & $1.41 \%$ \\
\hline India & 17 & $1.41 \%$ \\
\hline Switzerland & 17 & $1.41 \%$ \\
\hline New Zealand & 15 & $1.25 \%$ \\
\hline Turkey & 15 & $1.25 \%$ \\
\hline France & 12 & $1.00 \%$ \\
\hline Iran & 11 & $0.91 \%$ \\
\hline Japan & 11 & $0.91 \%$ \\
\hline Denmark & 10 & $0.83 \%$ \\
\hline
\end{tabular}

Notes: Countries with more than 10 articles are listed. 


\section{DISCUSSION}

The current study presented a bibliometric study of electronic commerce research articles published in five top tier electronic commerce research journals listed in the SSCI database. The current study collected 1,205 electronic commerce research articles in the period of 2000 to 2016 . We summary the highly influence electronic commerce research and the theoretical background of the electronic commerce research.

Even though the current study offered informative insights into the knowledge structure of electronic commerce research, it has some limitations. First, we include only articles published in the top tier electronic commerce journals listed in the SSCI database, which might influence the generalization of the study. Some electronic commerce research articles were published in the top tier journals of the fields of business, management information systems, computer science, information science, management, and marketing. Many high quality and high influence electronic commerce research articles were not included in our research scope. Besides, the current study only review the keywords of articles to find out the theoretical background of the electronic commerce research. Many articles did not provide their used theories as keywords. Thus, the theories for electronic commerce research are not all included in the list we summarized.

However, we still trust the study provides a valuable integration and different perspective on electronic commerce research. We believe that the current study would provide a useful briefing for newcomers of the field.

Table 3 Highly Influence Electronic Commerce Research Articles from 2000 to 2016

\begin{tabular}{|l|l|l|c|c|}
\hline \multicolumn{1}{|c|}{ Authors } & Year & \multicolumn{1}{|c|}{ Article Title } & Journal & Cited Times \\
\hline Pavlou (Pavlou, 2003) & 2003 & $\begin{array}{l}\text { Consumer acceptance of electronic } \\
\text { commerce: Integrating trust and risk } \\
\text { with the technology acceptance model }\end{array}$ & IJEC & 634 \\
\hline $\begin{array}{l}\text { Lee and Turban (M. } \\
\text { K. Lee \& Turban, } \\
\text { 2001) }\end{array}$ & 2001 & $\begin{array}{l}\text { A trust model for consumer Internet } \\
\text { shopping }\end{array}$ & IJEC & 339 \\
\hline $\begin{array}{l}\text { Park, Lee, and Han } \\
\text { (Park et al., 2007) }\end{array}$ & 2007 & $\begin{array}{l}\text { The effect of on-line consumer reviews } \\
\text { on consumer purchasing intention: The } \\
\text { moderating role of involvement }\end{array}$ & IJEC & 274 \\
\hline $\begin{array}{l}\text { McKnight and } \\
\text { Chervany (D Harrison } \\
\text { McKnight, 2001) }\end{array}$ & 2001 & $\begin{array}{l}\text { What trust means in e-commerce } \\
\text { customer relationships: An } \\
\text { interdisciplinary conceptual typology }\end{array}$ & IJEC \\
\hline
\end{tabular}


Table 3 Highly Influence Electronic Commerce Research Articles from 2000 to 2016 (Continued)

\begin{tabular}{|c|c|c|c|c|}
\hline Authors & Year & Article Title & Journal & Cited Times \\
\hline $\begin{array}{l}\text { DeLone and McLean } \\
\text { (Delone \& Mclean, } \\
\text { 2004) }\end{array}$ & 2004 & $\begin{array}{l}\text { Measuring e-commerce success: } \\
\text { Applying the DeLone \& McLean } \\
\text { information systems success model }\end{array}$ & IJEC & 260 \\
\hline $\begin{array}{l}\text { Tsang and Liang } \\
\text { (Tsang, Ho, \& Liang, } \\
\text { 2004) }\end{array}$ & 2004 & $\begin{array}{l}\text { Consumer attitudes toward mobile } \\
\text { advertising: An empirical study }\end{array}$ & IJEC & 193 \\
\hline Lee (M.-C. Lee, 2009) & 2009 & $\begin{array}{l}\text { Factors influencing the adoption of } \\
\text { internet banking: An integration of TAM } \\
\text { and TPB with perceived risk and } \\
\text { perceived benefit }\end{array}$ & ECRA & 168 \\
\hline $\begin{array}{l}\text { Suh and Han (Suh \& } \\
\text { Han, 2003) }\end{array}$ & 2003 & $\begin{array}{l}\text { The impact of customer trust and } \\
\text { perception of security control on the } \\
\text { acceptance of electronic commerce }\end{array}$ & IJEC & 157 \\
\hline $\begin{array}{l}\text { Hennig-Thurau and } \\
\text { Walsh } \\
\text { (Hennig-Thurau, } \\
\text { Walsh, \& Walsh, } \\
\text { 2003) }\end{array}$ & 2003 & $\begin{array}{l}\text { Electronic word-of-mouth: Motives for } \\
\text { and consequences of reading customer } \\
\text { articulations on the Internet }\end{array}$ & IJEC & 149 \\
\hline $\begin{array}{l}\text { Cheung, Luo, Sia, and } \\
\text { Chen (Cheung, Luo, } \\
\text { Sia, \& Chen, 2009) }\end{array}$ & 2009 & $\begin{array}{l}\text { Credibility of Electronic } \\
\text { Word-of-Mouth: Informational and } \\
\text { Normative Determinants of On-line } \\
\text { Consumer Recommendations }\end{array}$ & IJEC & 146 \\
\hline $\begin{array}{l}\text { Westland (Westland, } \\
\text { 2010) }\end{array}$ & 2010 & $\begin{array}{l}\text { Lower bounds on sample size in } \\
\text { structural equation modeling }\end{array}$ & ECRA & 133 \\
\hline $\begin{array}{l}\text { Lee, Park, and Han (J. } \\
\text { Lee, Park, \& Han, } \\
\text { 2008) }\end{array}$ & 2008 & $\begin{array}{l}\text { The effect of negative online consumer } \\
\text { reviews on product attitude: An } \\
\text { information processing view }\end{array}$ & ECRA & 132 \\
\hline Zwass (Zwass, 2010) & 2010 & $\begin{array}{l}\text { Co-Creation: Toward a Taxonomy and } \\
\text { an Integrated Research Perspective }\end{array}$ & IJEC & 121 \\
\hline $\begin{array}{l}\text { Koh and Kim (Koh, } \\
\text { Kim, \& Kim, 2003) }\end{array}$ & 2003 & $\begin{array}{l}\text { Sense of virtual community: A } \\
\text { conceptual framework and empirical } \\
\text { validation }\end{array}$ & IJEC & 112 \\
\hline $\begin{array}{l}\text { Barnes and Vidgen } \\
\text { (Barnes \& Vidgen, } \\
2001 \text { ) }\end{array}$ & 2001 & $\begin{array}{l}\text { An evaluation of cyber-bookshops: The } \\
\text { WebQual method }\end{array}$ & IJEC & 111 \\
\hline $\begin{array}{l}\text { Balasubramanian and } \\
\text { Mahajan(Sridhar } \\
\text { Balasubramanian, } \\
\text { 2001) }\end{array}$ & 2001 & $\begin{array}{l}\text { The economic leverage of the virtual } \\
\text { community }\end{array}$ & IJEC & 111 \\
\hline
\end{tabular}


Table 3 Highly Influence Electronic Commerce Research Articles from 2000 to 2016 (Continued)

\begin{tabular}{|l|c|l|c|c|}
\hline \multicolumn{1}{|c|}{ Authors } & Year & \multicolumn{1}{c|}{ Article Title } & Journal & Cited Times \\
\hline $\begin{array}{l}\text { Rust and Lemon (Rust } \\
\text { \& Lemon, 2001) }\end{array}$ & 2001 & E-service and the consumer & IJEC & 106 \\
\hline $\begin{array}{l}\text { Park and Kim (Park \& } \\
\text { Kim, 2009) }\end{array}$ & 2008 & $\begin{array}{l}\text { The effects of consumer knowledge on } \\
\text { message processing of electronic } \\
\text { word-of-mouth via online consumer } \\
\text { reviews }\end{array}$ & ECRA & 104 \\
\hline $\begin{array}{l}\text { Koufaris, Kambil, } \\
\text { and LaBarbera } \\
\text { (Koufaris \& Ajit }\end{array}$ & 2001 & $\begin{array}{l}\text { Consumer behavior in Web-based } \\
\text { commerce: An empirical study }\end{array}$ & IJEC & 100 \\
\hline $\begin{array}{l}\text { Kambil, 2001) } \\
\text { Kauffman and Walden } \\
\text { Kauffman \& Walden, } \\
\text { 2001) }\end{array}$ & 2001 & $\begin{array}{l}\text { Economics and electronic commerce: } \\
\text { Survey and directions for research }\end{array}$ & IJEC & 100 \\
\hline
\end{tabular}

Notes: Cited times were search results of SSCI database in January 5, 2017. ECRA: Electronic Commerce Research and Applications, IJEC: International Journal of Electronic Commerce.

Table 4 Theories Mentioned in Electronic Commerce Research Articles from 2000

\begin{tabular}{|c|c|c|c|}
\hline \multicolumn{4}{|c|}{ to 2016} \\
\hline $\begin{array}{c}\text { 3M Model of } \\
\text { Motivation And } \\
\text { Personality } \\
\end{array}$ & Flow theory & IS Success Model & $\begin{array}{l}\text { Recency, Frequency, and } \\
\text { Monetary Model }\end{array}$ \\
\hline Adverse Selection & Gibrat's Law & Pareto Law & Social Identity Theory \\
\hline Anchoring Effect & Goal Gradient Theory & Percolation Theory & Social Justice Theory \\
\hline Attribution Theory & Graph Theory & Perspective Model & $\begin{array}{l}\text { Stimulus-Organism-Response } \\
\text { (S-O-R) Model }\end{array}$ \\
\hline Auction Theory & Grounded Theory & Persuasion Theory & Status Quo Bias Theory \\
\hline Clustering Theory & Growth Theory & Prospect Theory & Strategic Fit Theory \\
\hline Cognitive Fit Theory & $\begin{array}{l}\text { Heuristic-Systematic } \\
\text { Dual-Processing Model } \\
\text { (HSM) }\end{array}$ & $\begin{array}{l}\text { Protection Motivation } \\
\text { Theory }\end{array}$ & Structuration Theory \\
\hline $\begin{array}{l}\text { Collective Cognition } \\
\text { Theory }\end{array}$ & Homophily Theory & Reed's Law & Systems Theory \\
\hline Decision Theory & $\begin{array}{l}\text { Information Cascade } \\
\text { Theory }\end{array}$ & $\begin{array}{l}\text { Reputation- and } \\
\text { Trust-Based Model } \\
\text { (RTM) }\end{array}$ & $\begin{array}{l}\text { Technology Acceptance } \\
\text { Model (TAM) }\end{array}$ \\
\hline $\begin{array}{l}\text { Decomposed Theory } \\
\text { of Planned Behavior }\end{array}$ & $\begin{array}{l}\text { Innovation Diffusion } \\
\text { Theory }\end{array}$ & $\begin{array}{l}\text { Resource-Based } \\
\text { Model }\end{array}$ & $\begin{array}{l}\text { The Unified Theory of Use } \\
\text { and Acceptance Of } \\
\text { Technology (UTAUT) }\end{array}$ \\
\hline
\end{tabular}




\section{REFERENCES}

Barnes, S. J., \& Vidgen, R. (2001). An evaluation of cyber-bookshops: the WebQual method. International journal of electronic commerce, 6(1), 11-30. http://dx.doi.org/10.1080/10864415.2001.11044225

Cheung, M. Y., Luo, C., Sia, C. L., \& Chen, H. (2009). Credibility of electronic word-of-mouth: Informational and normative determinants of on-line consumer recommendations. International journal of electronic commerce, 13(4), 9-38. http://dx.doi.org/10.2753/JEC1086-4415130402

D Harrison McKnight, N. L. C. (2001). What trust means in e-commerce customer relationships: An interdisciplinary conceptual typology. International journal of electronic commerce, 6(2), 35-59. DOI:10.1080/10864415.2001.11044235

Delone, W. H., \& Mclean, E. R. (2004). Measuring e-commerce success: Applying the DeLone \& McLean information systems success model. International journal of electronic commerce, 9(1), 31-47.

Hennig-Thurau, T., Walsh, G., \& Walsh, G. (2003). Electronic word-of-mouth: Motives for and consequences of reading customer articulations on the Internet. International journal of electronic commerce, 8(2), 51-74. http://dx.doi.org/10.1002/dir.10073

Kauffman, R. J., \& Walden, E. A. (2001). Economics and electronic commerce: Survey and directions for research. International journal of electronic commerce, 5(4), 5-116.

Koh, J., Kim, Y.-G., \& Kim, Y.-G. (2003). Sense of virtual community: A conceptual framework and empirical validation. International journal of electronic commerce, 8(2), 75-94.

Koufaris, M., \& Ajit Kambil, P. A. L. (2001). Consumer behavior in web-based commerce: an empirical study. International journal of electronic commerce, 6(2), 115-138.

Lee, J., Park, D.-H., \& Han, I. (2008). The effect of negative online consumer reviews on product attitude: An information processing view. Electronic commerce research and applications, 341-352. https://doi.org/10.1016/j.elerap.2007.05.004

Lee, M.-C. (2009). Factors influencing the adoption of internet banking: An integration of TAM and TPB with perceived risk and perceived benefit. Electronic commerce research and applications, 8(3), 130-141. http://dx.doi.org/10.1016/j.elerap.2008.11.006

Lee, M. K., \& Turban, E. (2001). A trust model for consumer internet shopping. International journal of electronic commerce, 6(1), 75-91. 
Ngai, E. W., \& Wat, F. (2002). A literature review and classification of electronic commerce research. Information \& Management, 39(5), 415-429. http://dx.doi.org/10.1016/S0378-7206(01)00107-0

Park, D.-H., \& Kim, S. (2009). The effects of consumer knowledge on message processing of electronic word-of-mouth via online consumer reviews. Electronic commerce research and applications, 7(4), 399-410. http://dx.doi.org/10.1016/j.elerap.2007.12.001

Park, D.-H., Lee, J., \& Han, I. (2007). The effect of on-line consumer reviews on consumer purchasing intention: The moderating role of involvement. International journal of electronic commerce, 11(4), 125-148. http://dx.doi.org/10.2753/JEC1086-4415110405

Pavlou, P. A. (2003). Consumer acceptance of electronic commerce: Integrating trust and risk with the technology acceptance model. International journal of electronic commerce, 7(3), 101-134.

Rust, R. T., \& Lemon, K. N. (2001). E-service and the consumer. International journal of electronic commerce, 5(3), 85-101.

Sridhar Balasubramanian, V. M. (2001). The economic leverage of the virtual community. International journal of electronic commerce, 5(3), 103-138.

Suh, B., \& Han, I. (2003). The impact of customer trust and perception of security control on the acceptance of electronic commerce. International journal of electronic commerce, 7(3), 135-161.

Tsang, M. M., Ho, S.-C., \& Liang, T.-P. (2004). Consumer attitudes toward mobile advertising: An empirical study. International journal of electronic commerce, 8(3), 65-78.

Westland, J. C. (2010). Lower bounds on sample size in structural equation modeling. Electronic commerce research and applications, 9(6), 476-487. http//dx.doi.org/10.1016/j.elerap.2010.07.003

Zwass, V. (2010). Co-creation: Toward a taxonomy and an integrated research perspective. International journal of electronic commerce, 15(1), 11-48. http://dx.doi.org/10.2753/JEC1086-4415150101 